\title{
Amnion-derived cells express intercellular adhesion molecule-1: regulation by cytokines
}

\section{K W Marvin, W R Hansen, H C Miller, R L Eykholt and M D Mitchell}

\author{
Department of Pharmacology and Clinical Pharmacology, University of Auckland, Private Bag 92019, \\ Auckland, New Zealand \\ (Requests for offprints should be addressed to K W Marvin)
}

\begin{abstract}
We have examined the expression of the intercellular adhesion molecule-1 (ICAM-1) mRNA in primary and established amnion-derived cell cultures and regulation of this expression by tumour necrosis factor- $\alpha$ (TNF- $\alpha$ ) and interleukin (IL) $-1 \beta$. TNF- $\alpha(50 \mathrm{ng} / \mathrm{ml})$ and IL-1 $\beta(1 \cdot 0 \mathrm{ng} / \mathrm{ml})$ induced 18 - and 11-fold increases respectively in expression of the ICAM-1 mRNA in WISH cells (an amnion epithelium-derived cell line). The increase was detectable within one hour of treatment and peaked by two hours. The protein synthesis inhibitor, cycloheximide $(10 \mu \mathrm{g} / \mathrm{ml})$ did not inhibit this induction. Increased levels of ICAM-1 protein were detected in the cells within $4 \mathrm{~h}$ after initiation of treatment with either cytokine. By $16 \mathrm{~h}$ of treatment with IL-1 $\beta$ or TNF- $\alpha$ ICAM-1 reached 40 and $73 \mathrm{pg} / \mu \mathrm{g}$ cellular protein, representing $6-$ and
\end{abstract}

11-fold stimulations respectively. In primary amnion cells, basal expression of ICAM-1 mRNA was undetectable. However, TNF- $\alpha(50 \mathrm{ng} / \mathrm{ml})$ induced ICAM-1 mRNA within two hours, peak expression being reached between four and eight hours after initiation of treatment. The present report demonstrates for the first time that amnion derived cells can express ICAM-1 and, further, that this expression is regulated by pro-inflammatory cytokines. This has implications for the amnion as a possible source for soluble ICAM-1, for this gene product as a marker for preterm labour, and for participation of the amnion, additional to its reported secretory role, in inflammatory processes of the fetal membranes.

Fournal of Molecular Endocrinology (1999) 22, 193-205

\section{INTRODUCTION}

The principal cause of perinatal morbidity and mortality is preterm delivery (McCormick 1985, Committee to Study the Prevention of Low Birthweight, Division of Health Promotion and Disease Prevention, Institute of Medicine 1985). While preterm delivery occurs at a rate of $10 \%$ of live births (Creasy 1993), preterm infants account for approximately $80 \%$ of perinatal mortality (Copper et al. 1993). Furthermore, those surviving have a 22 -fold higher morbidity rate than term infants (Scott \& Spiker 1989, Morrison 1990). Thus, studies into the mechanisms of preterm labour address a very significant health problem.

Although drug intervention into the process of preterm labour may permit a significant maturation of the fetal lungs and other organs (Gardner \& Goldenberg 1995), success in reducing the incidence of preterm labour has been minimal (Higby et al. 1993). In addition, clinical diagnosis of preterm labour based on contractions and other symptoms suffers from low positive predictive values and sensitivities (Creasy 1993, Iams et al. 1994, Lockwood 1995, Mercer et al. 1996). Furthermore, a high percentage (30-50\%) of women presenting with apparent preterm labour ultimately deliver at term. Thus, both better understanding of the processes underlying preterm labour and improvement of diagnostic tools are required to assist in the management and treatment of women presenting with preterm labour.

Studies of abnormal localisation or expression of cell adhesion molecules or extracellular matrix proteins show considerable promise in these areas. Fetal fibronectin (fFN) measurement has received the most attention as a diagnostic tool. The presence of this extracellular matrix protein in cervical vaginal fluid predicts preterm delivery among women at high risk but with intact membranes 
(Lockwood et al. 1993, Inglis et al. 1994). Cell adhesion molecules in the intrauterine environment, on the other hand, have principally been studied in relation to implantation and early placentation (Damsky et al. 1993, 1994, Kwee et al. 1995, Yang et al. 1995), or pre-eclampsia and intrauterine growth restriction (IUGR) (Labarrere \& Faulk 1995, Lyall et al. 1995). Notably, in one such study the concentration of the soluble form of intercellular adhesion molecule-1 (ICAM-1) in the amniotic fluid correlated strongly with shortened gestation and IUGR (Salafia et al. 1993).

ICAM-1, an immunoglobulin superfamily cell adhesion molecule, is well known as an inflammatory mediator promoting the adhesion of neutrophils or other leukocytes to the endothelium prior to emigration into inflamed tissues (Springer 1990, 1994, Carlos \& Harlan 1994). Like the genes for prostaglandin $\mathrm{H}$ synthase 2 (PGHS-2) (Tazawa et al. 1994) and the cytokine interleukin (IL)-1 $\beta$ (Hiscott et al. 1993), the ICAM-1 gene has a cytokine inducible promoter (Ledebur \& Parks 1995, Roebuck et al. 1995). All three promoters contain nuclear factor- $\kappa \mathrm{B}$ responsive elements, which partially mediate this effect (Hiscott et al. 1993, Tazawa et al. 1994, Ledebur \& Parks 1995).

Since secretion of inflammatory cytokines in the intrauterine environment is often associated with preterm labour (Inglis et al. 1994), especially in association with intrauterine infection (Romero et al. 1989a,b), ICAM-1 expression would be expected in a much broader range of preterm deliveries than so far reported (Salafia et al. 1993). Further, since there have been several reports of ICAM-1 expression in epithelia or epithelial cells, particularly during inflammation (Sippy et al. 1995, Ciprandi et al. 1996, Khair et al. 1996, Iwata et al. 1997), it is reasonable to suggest that the amnion might also be able to express this gene. In order to test this hypothesis, we have studied the ability of the inflammatory cytokines IL-1 $\beta$ and tumour necrosis factor- $\alpha$ (TNF- $\alpha$ ) to regulate the expression of ICAM-1 in cultures of WISH cells (an amnion epithelium-derived cell line) and primary cultures of amnion cells.

\section{METHODS AND MATERIALS}

\section{Cell culture}

Primary amnion cell cultures were established as previously described (Keelan et al. 1997a). Briefly, placentae were obtained, with informed consent, from women undergoing repeat caesarean section at term prior to labour at National Women's Hospital, New Zealand. The amnions were peeled from the chorion laeve and dispersed by successive treatment with $0.024 \%$ collagenase (Boehringer Mannheim NZ Ltd, Auckland, New Zealand) and 1.2\% trypsin (Life Technologies Inc., Gaithersburg, MD, USA). The dispersed cells were plated in 1:1 Ham's F12:Dulbecco's modified Eagle's medium (F12/ DMEM, Irvine Scientific, Irvine, CA, USA) supplemented with $10 \%$ heat treated fetal bovine serum (FBS, Life Technologies Inc.) at $1 \cdot 2 \times 10^{5} /$ $\mathrm{cm}^{2}$ in 6-cm dishes (Falcon, Becton-Dickenson, Lincoln Park, NJ, USA). Media were changed $24 \mathrm{~h}$ after plating and at 48-h intervals thereafter. Ethical approval for collection and use of human placental tissue was obtained from the Ethics Committee of the Northern Regional Health Authority of New Zealand and the North Health Division of the Transitional Health Authority of New Zealand.

WISH cells (Hayflick 1961), a kind gift from Dr Les Myatt, University of Cincinnati, USA, were grown in F12/DMEM supplemented as for amnion cell culture. Media changes were performed every $48 \mathrm{~h}$ (Hansen et al. 1998). The plating densities were $3 \times 10^{5}$ cells/well of a 24 -well culture plate or $3 \times 10^{6}$ of a $6-\mathrm{cm}$ dish. HL60 cells, a kind gift from Dr Kathryn Crosier, University of Auckland, New Zealand, were grown in RPMI 1640 supplemented with $20 \%$ heat-treated fetal calf serum at a density of $1 \times 10^{6}$ cells per $\mathrm{ml}$.

\section{Experimental conditions}

TNF- $\alpha$, a kind gift from Dr John Fraser, University of Auckland, New Zealand, and IL-1 $\beta$ (Immunex, Seattle, WA, USA) were prepared as 100 -fold concentrates in $12 \mathrm{mM} \mathrm{Na} \mathrm{HPO}_{4}, 3.9 \mathrm{mM}$ $\mathrm{KH}_{2} \mathrm{PO}_{4}, 145 \mathrm{mM} \mathrm{NaCl}, 1 \%$ bovine serum albumin fraction $\mathrm{V}$ (BSA) (SERVA, Boehringer Ingelheim Bioproducts Partnership, Heidelberg, Germany). Cycloheximide (CHX) and retinoic acid (RA), both purchased from Sigma Chemical Co. (St Louis, MO, USA) were dissolved in ethanol at $10 \mathrm{mg} / \mathrm{ml}$ and $10^{-5} \mathrm{M}$ respectively. Confluent cultures of amnion (day 5 of culture) or WISH cells were treated with TNF- $\alpha$ or IL-1 $\beta$ as noted in the figure legends. When used CHX was applied at $10 \mu \mathrm{g} / \mathrm{ml}$, $30 \mathrm{~min}$ prior to experimental treatment. HL60 cells were treated with $5 \times 10^{-8} \mathrm{M} \mathrm{RA}$ for four days to induce differentiation.

\section{Preparation of RNA}

Total RNA was isolated by the guanidinium thiocyanate (GTC)-acid phenol method (Chomczynski \& Sacchi 1987). Adherent cell cultures were directly scraped in the GTC lysis solution and suspension cells were collected by centrifugation before direct 
resuspension in that solution. The RNA was dissolved in formamide (Chomczynski 1992) and stored at $-70{ }^{\circ} \mathrm{C}$.

\section{Preparation of ICAM-1 cDNA}

Reverse transcription PCR (RT-PCR) was used to prepare ICAM-1 cDNA from total RNA isolated from RA-induced HL60 cells. The reported sequence for ICAM-1 cDNA (GenBank Accession g184532, Tomassini et al. 1989) was retrieved with the aid of the Wisconsin Package version 9.1, Genetics Computer Group (GCG) (Madison, WI, USA) sequence analysis software. Primer design was performed using Oligo version 4.01 (National Bioscience, Plymouth, MN, USA). The primer sequences are listed in Fig. 1. One microlitre $(0.5 \mu \mathrm{g}) \quad \mathrm{RNA}$ and $10 \mathrm{pmol}$ primer P3 were combined in $12 \mu \mathrm{l}$ diethylpyrocarbonate (Sigma Chemical Co.)-treated milliQ (Millipore, Bedford, MA, USA) purified water. The RNA was denatured for $1 \mathrm{~min}$ at $95{ }^{\circ} \mathrm{C}$, annealed at $58.5{ }^{\circ} \mathrm{C}$ for $5 \mathrm{~min}$ and transferred to ice. Reverse transcription was performed with $200 \mathrm{U}$ Superscript II RT (Life Technologies Inc.) in a $20 \mu \mathrm{l}$ reaction at $42{ }^{\circ} \mathrm{C}$ for $1 \mathrm{~h}$. Primary amplification to produce the $2.9 \mathrm{~kb}$ cDNA was performed with the Expand Long Template System (Boehringer Mannheim NZ Ltd) using $1 \mu \mathrm{l}$ of the reverse transcription reaction and 10 pmol each of primers P1 and P3. After a 2-min denaturation step at $94^{\circ} \mathrm{C}, \mathrm{PCR}$ was performed for 30 cycles of $1 \mathrm{~min}$ at $94^{\circ} \mathrm{C}, 1 \mathrm{~min}$ at $63{ }^{\circ} \mathrm{C}$, and $2 \mathrm{~min}$ at $68^{\circ} \mathrm{C}$. The initial $2.9 \mathrm{~kb}$ product was gel purified and used as the template for reamplification with $\mathrm{P} 1$ and $\mathrm{P} 2$ to prepare the $1.5 \mathrm{~kb}$ probe or $\mathrm{P} 1$ and $\mathrm{P} 3$ to prepare the $2.9 \mathrm{~kb}$ probe.

\section{Restriction analysis}

Restriction endonuclease digests were prepared using 40-60 ng PCR product and one unit of enzyme per reaction. Digestions were performed by incubating for $1 \mathrm{~h}$ at the temperature recommended by the enzyme supplier. The restriction endonucleases used, EcoRI, ApaI, KpnI and SmaI, were obtained from Boehringer-Mannheim NZ Ltd. Digestion products were separated on a $1 \%$ agarose, Tris-acetate-EDTA buffered gel. Predicted fragment sizes were determined using the Wisconsin Package version 9.1, (GCG) sequence analysis software.

\section{Northern blot analysis}

Fifteen micrograms RNA were loaded per lane on $1 \%$ agarose, MOPS-formaldehyde gels (Sambrook et al. 1989). The RNA was transferred from the gels to Gene Screen Plus (NEN Life Science Products, Boston, MA, USA) by the capillary method (Sambrook et al. 1989), and crosslinked to the wet membrane by ultraviolet light, $1200 \mathrm{~J} / \mathrm{m}^{2}$, using a Stratalinker (Stratagene, La Jolla, CA, USA). cDNA probes were labelled with $\left[\alpha^{32} \mathrm{P}\right] \mathrm{d}-$ CTP (Amersham International plc, Amersham, Bucks, UK) by random primed synthesis using a Mega Prime Kit (Amersham International plc). Hybridisation was carried out as described (Vollberg et al. 1991, Marvin et al. 1992) or, where noted, at $68{ }^{\circ} \mathrm{C}$ in QuikHyb solution (Stratagene). Progressive stringency washing was performed using $2 \times, 0.5 \times$ and $0.1 \times \mathrm{SSC}$ with $0 \cdot 1 \%$ sodium dodecylsulphate (Serva, Boehringer Ingelheim Bioproducts Partnership) at 22, 55 and $60{ }^{\circ} \mathrm{C}$ respectively (Vollberg et al. 1991, Brown \& Mackey 1997). Detection was performed by electronic autoradiography at $200 \mu \mathrm{m}$ resolution using a Storm 860 phosphor imager (Molecular Dynamics, Sunnyvale, CA, USA) or, where noted, $500 \mu \mathrm{m}$ resolution using an InstantImager (Packard, Canberra, Australia). The manufacturer's image analysis software was utilised for quantitation. The probes used were the $1.5 \mathrm{~kb}$ ICAM-1 cDNA (unless otherwise noted) and a human glyceraldehyde-3-phosphate dehydrogenase (GAPDH) cDNA (Tso et al. 1985). The size of the detected mRNA was estimated from its mobility and those of the components of a 0.24-9.5 kb RNA ladder (Life Technologies Inc.) marker using the GROWTH function of the EXCEL spreadsheet program (Microsoft Corp., Redmond, WA, USA).

\section{Cell lysis and extraction for protein analysis}

Cellular extracts were prepared with Reporter Gene Assay Lysis buffer (Boehringer-Mannheim) supplemented with $0.2 \mathrm{mM}$ phenylmethylsulphonyl fluoride (Sigma Chemical Co.), $2 \times 200 \mu \mathrm{l} /$ well of a 24-well culture dish, with the aid of a rubber policeman. This is a hypotonic lysis buffer containing $0 \cdot 5 \%$ Triton-X 100 . The lysates were rapidly frozen and stored at $-70{ }^{\circ} \mathrm{C}$ until assayed. Prior to assay the samples were rapidly thawed and centrifuged for $5 \mathrm{~min}$ at $15000 \mathrm{~g}$ at $4{ }^{\circ} \mathrm{C}$.

Extracted cellular protein was measured by the bicinchoninic acid (BCA) method (Redinbaugh \& Turley 1986). The assay was calibrated with BSA. Optical densities were measured on a Spectramax UV ELISA plate reader (Molecular Devices, Palo Alto, CA, USA) at $562 \mathrm{~nm}$. 


\section{ICAM-1 immunoassay}

Enzyme-linked immunosorbent assay (ELISA) for ICAM-1 was performed using a matched pair of anti-human ICAM-1 monoclonal antibodies, clone $15 \cdot 2$ and clone 8.4A6 (biotinylated) (Ancell Corp., Bayport, MN, USA). These recognize domains D1 and D2 respectively of ICAM-1. FluoroNunc ELISA plates (Nunc A/S, Roskilde, Denmark) were coated with clone $15 \cdot 2$ antibody $(50 \mu \mathrm{l} /$ well of $2 \mu \mathrm{g} / \mathrm{ml}$ ) in $35 \mathrm{mM} \mathrm{Na} \mathrm{NaO}_{4}, 18 \mathrm{mM} \mathrm{Na} \mathrm{NO}_{3}$, $14 \mathrm{mM} \mathrm{NaCl}, 0.02 \% \mathrm{NaN}_{3}, \mathrm{pH} 8.8$ overnight at $4{ }^{\circ} \mathrm{C}$. Residual binding sites were blocked with the assay diluent $(10 \%$ heat-treated FBS in $10 \mathrm{mM}$ $\mathrm{NaH}_{2} \mathrm{PO}_{4}-\mathrm{Na}_{2} \mathrm{HPO}_{4}$, pH 7.4, $130 \mathrm{mM} \mathrm{NaCl}, 0 \cdot 5 \%$ NP-40, $0 \cdot 02 \% \mathrm{NaN}_{3}$ ). Recombinant human soluble (s)ICAM-1 (R\&D Systems, Minneapolis, MN, USA) was used as a standard. Samples, diluted as required, and serial dilutions of the standard were prepared such that the final buffer was composed of equal proportions of the assay diluent and lysis buffer. The standards and samples $(50 \mu \mathrm{l} /$ well $)$ were incubated in the coated ELISA plates overnight at $4{ }^{\circ} \mathrm{C}$. The plates were washed in $50 \mathrm{mM}$ Tris- $\mathrm{HCl}$, pH $7 \cdot 2, \quad 300 \mathrm{mM} \mathrm{NaCl}, \quad 0 \cdot 5 \%$ Tween 20 and the biotinylated antibody was added $(50 \mu \mathrm{l} /$ well of $500 \mathrm{ng} / \mathrm{ml}$ antibody in $80 \mathrm{mM} \mathrm{NaH}_{2} \mathrm{PO}_{4}$ $\mathrm{Na}_{2} \mathrm{HPO}_{4}, \mathrm{pH} 7 \cdot 0,6 \cdot 4 \mathrm{mM}$ EDTA, $27 \mathrm{mM} \mathrm{NaCl}$, $0 \cdot 5 \%$ Tween-20, $0 \cdot 3 \%$ BSA, $0.02 \%$ thiomerasol). After incubation for $2 \mathrm{~h}$ at room temperature, StreptABComplex/AP (Dako Corp., Carpinteria, CA, USA) was applied $(50 \mu \mathrm{l} /$ well at a 1 in 25 dilution) and the plates incubated for a further $1 \mathrm{~h}$ at room temperature. After a final series of washes, $100 \mu \mathrm{l} /$ well methylumbelliferyl phosphate (Sigma Chemical Co. $)\left(0.01 \mathrm{mg} / \mathrm{ml}\right.$ in $0.1 \mathrm{NaHCO}_{3}$ $\mathrm{Na}_{2} \mathrm{CO}_{3}$ buffer, $\left.\mathrm{pH} 9 \cdot 5\right)$ were added. Fluorescence was measured after $4 \mathrm{~h}$ with a Victor multilabel counter (Wallac OY, Turku Finland). Analysis of the data was performed using MultiCalc software (Wallac OY). The sensitivity of the assay was $0.3 \mathrm{ng} / \mathrm{ml} \mathrm{sICAM}-1$ with an upper limit of at least $20 \mathrm{ng} / \mathrm{ml}$. Intraplate and interplate variability were $10 \%$ and $13 \%$ respectively. Human plasma and a non-recombinant ICAM-1 standard extracted from cultured human cells (Ancell) have been used to further verify the assay.

\section{Expression of data and statistical analysis}

ICAM-1 mRNA data are expressed as percentage of a common reference sample (RNA extracted from WISH cells treated for two hours with $1.0 \mathrm{ng} / \mathrm{ml}$ IL-1 $\beta$ ) for all experiments. ICAM-1 protein is

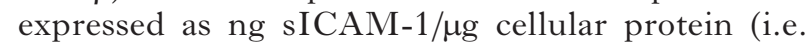
not corrected for the difference in the molecular

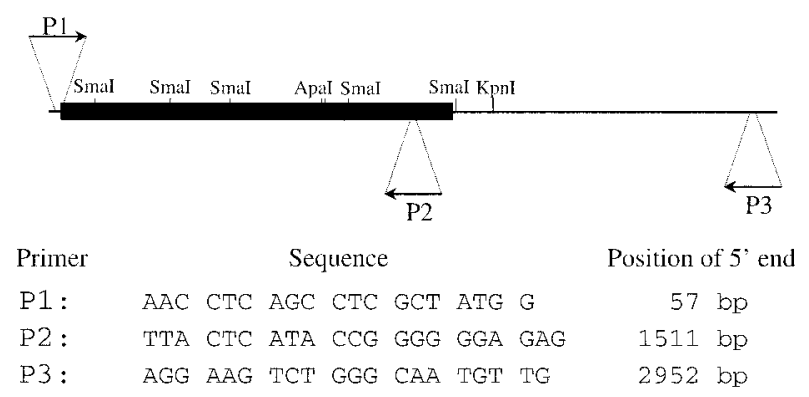

FIGURE 1. Map of the locations of the primers used to prepare the RT-PCR derived ICAM-1 cDNA probes on the reported cDNA sequence for ICAM-1. ( $)$ coding region; (-) untranslated regions; $(\rightarrow)$ primers.

Forward primers are noted above the cDNA and reverse primers below the map. Several restriction sites useful for characterization of ICAM-1 cDNA are indicated.

weights of the soluble and membrane spanning forms). Statistical significance was assessed by use of one-way analysis of variance followed by application of the Student-Newman-Keuls test.

\section{RESULTS}

\section{Characterization of the ICAM-1 PCR products}

A map of the locations of the primers on the reported sequence for ICAM-1 (GenBank Accession g184532, Tomassini et al. 1989) is shown in Fig. 1. The recognition sites for the restriction endonucleases used to confirm the identity of the products are also indicated. No EcoRI sites are present in the reported cDNA. Both ApaI and KpnI would be expected to cleave the full length ICAM-1 cDNA into two major fragments, but the latter would cut outside the smaller, $1.5 \mathrm{~kb}$, PCR product. Finally, five recognition sites for SmaI are predicted in ICAM-1 cDNA, four within the range of the $1.5 \mathrm{~kb}$ product.

As shown in Fig. 2, restriction endonucleases EcoRI, ApaI, KpnI and SmaI give the anticipated digestion patterns of the PCR-derived ICAM-1 probes. EcoRI cuts neither PCR product. Furthermore, KpnI cuts only the larger of the two PCR products, resulting in the expected two fragments. Again as expected, ApaI cleaves both products yielding the appropriate sized fragments. Finally, SmaI cleaved the smaller PCR product entirely to fragments of $0.5 \mathrm{~kb}$ or less. The expected $1.3 \mathrm{~kb}$ fragment was observed when the larger PCR product was digested with this enzyme.

Both PCR products detected a major transcript on northern blots of WISH and HL60 total RNA estimated from four independent northern blots 
A.

B.

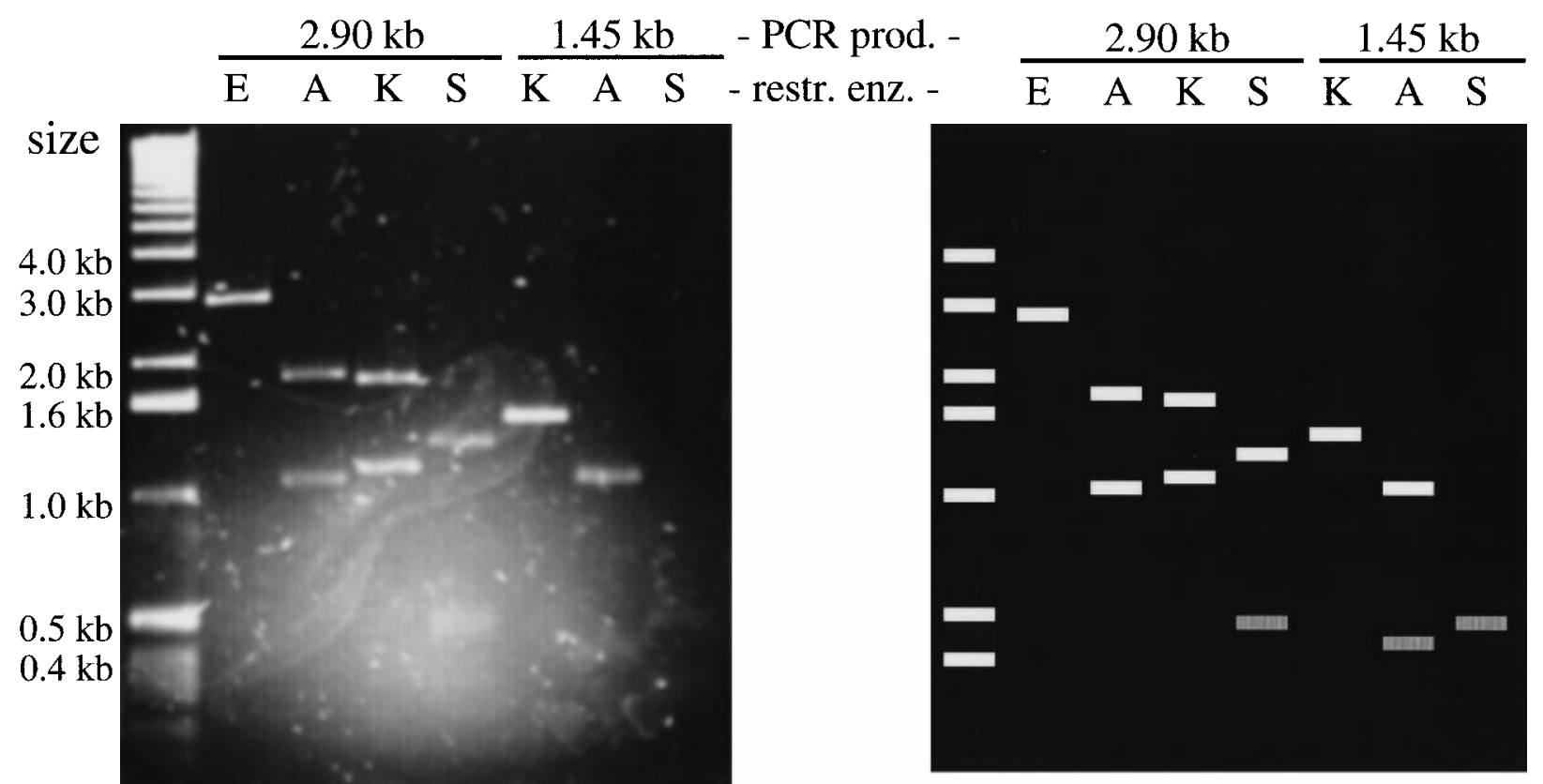

FIGURE 2. Restriction analysis of the ICAM-1 PCR products. (A) 1\% Agarose gel showing restriction digests of the 2.9 and $1.45 \mathrm{~kb}$ ICAM-1 PCR products (PCR prod.) digested with EcoRI (E), ApaI (A), KpnI (K) or SmaI (S) as noted above the gel. The first lane contains $250 \mathrm{ng}$ of a $1 \mathrm{~kb}$ ladder standard (Life Technologies Inc.). (B) Predicted digests plotted based on an exponential relationship of size in bp to mobility derived using the mobilities of the fragments from 507/516 through $4072 \mathrm{bp}$ of the $1 \mathrm{~kb}$ ladder and the LOGEST function of the EXCEL spreadsheet. restr. enz., restriction enzyme.

at $3 \cdot 2 \pm 0 \cdot 2 \mathrm{~kb}$ (mean \pm standard deviation), and a minor, smaller transcript of $2 \cdot 3 \pm 0 \cdot 1 \mathrm{~kb}$ (data not shown). The larger probe also detected a $0 \cdot 2 \mathrm{~kb}$ RNA but the smaller probe did not (data not shown).

\section{Time course of change in ICAM-1 mRNA in WISH cells treated with inflammatory cytokines}

TNF- $\alpha(50 \mathrm{ng} / \mathrm{ml})$ and IL-1 $\beta(1 \cdot 0 \mathrm{ng} / \mathrm{ml})$ both positively regulated the expression of ICAM- 1 mRNA in WISH cells, as shown in the depicted time course studies (Figs 3 and 4 respectively). In both cases, significantly elevated levels of ICAM-1 mRNA were detectable by $1 \mathrm{~h}$ and persisted through $16 \mathrm{~h}$. The maximum expression after treatment with either cytokine was attained by 2 h. For the TNF- $\alpha$ - and IL-1 $\beta$-treated cultures these maxima were $18 \pm 3$ and $11 \pm 3$-fold (mean \pm s.E.M.) respectively over the expression in the corresponding vehicle-treated controls. In the latter case expression at later time points had declined significantly from that at $2 \mathrm{~h}$. TNF- $\alpha$, however, consistently stimulated persistent maximal expression through the 8 - and 16-h time points. A trend towards a decline at the $4-\mathrm{h}$ time point was observed but was not statistically significant, although the difference between the expression at the 4 - and 8 -h points was significant $(P<0 \cdot 05)$. Basal expression was consistently detected and did not change significantly throughout the time courses. In some experiments, however, a small response appeared to occur in the vehicle-treated control samples.

\section{Concentration dependence of change in ICAM-1 mRNA in WISH cells treated with inflammatory cytokines}

Significant stimulation of ICAM-1 mRNA expression was observed with as little as $0.3 \mathrm{ng} / \mathrm{ml} \mathrm{TNF}-\alpha$ or $0 \cdot 1 \mathrm{ng} / \mathrm{ml} \mathrm{IL-1 \beta}$ (Fig. $5 \mathrm{~A}$ and B respectively). A concentration-dependent stimulation was observed through $50 \mathrm{ng} / \mathrm{ml}$ of the former and through $1 \mathrm{ng} / \mathrm{ml}$ of the latter. While higher concentrations of TNF- $\alpha$ might stimulate yet further, stimulation by IL-1 $\beta$ was maximal. The trend towards less 
A. $50 \mathrm{ng} / \mathrm{ml} \mathrm{TNF}-\alpha$ control

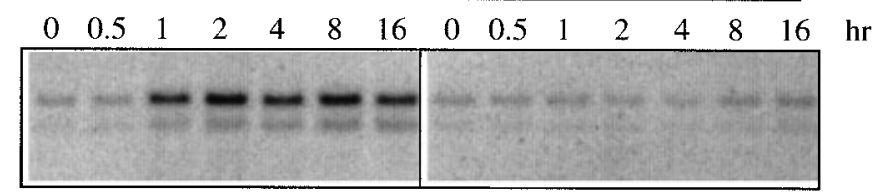

ICAM-1

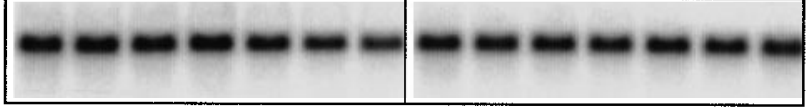

\section{GAPDH}

B.

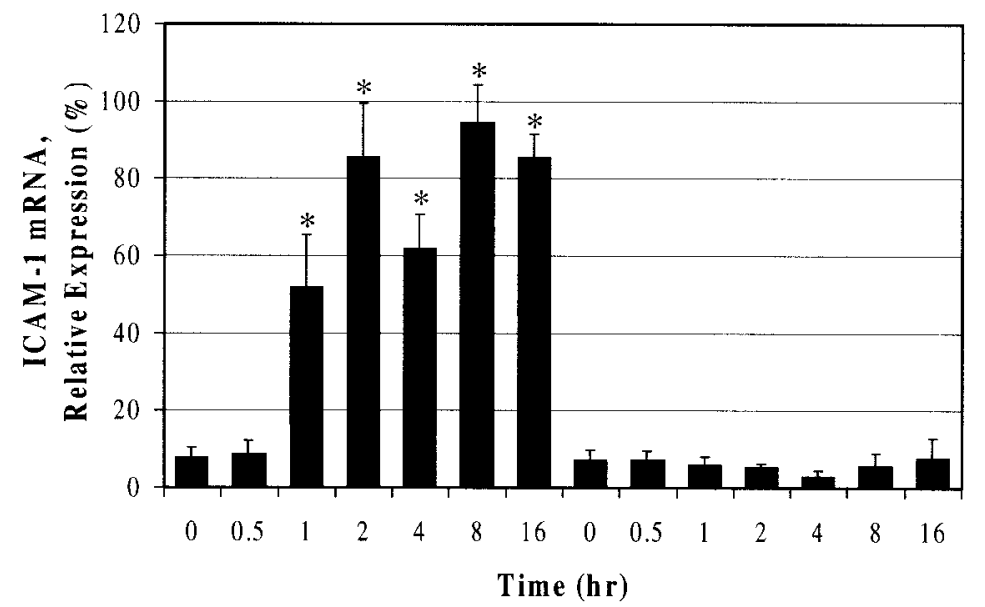

FIGURE 3. Time course of the stimulation of ICAM-1 mRNA expression in WISH cells following treatment with TNF- $\alpha$. WISH cells were treated with either $50 \mathrm{ng} / \mathrm{ml} \mathrm{TNF}-\alpha$ or vehicle and total RNA was extracted after $0,0 \cdot 5,1,2,4,8$, or $16 \mathrm{~h}$. (A) Representative northern blot probed for ICAM-1 and GAPDH: the treatments and times were as indicated above the blot. (B) Quantitative representation of ICAM-1 mRNA expression over the above time course. The data have been normalised to GAPDH and expressed relative to a common reference sample. They are plotted as means \pm s.E.M. $(n=4$ independent experiments at the 2 -h time point, $n=3$ at all other points); $*<0 \cdot 05$, significantly greater than the zero hour and corresponding vehicle-treated controls (Student-Newman-Keuls test). The 2-, 8-, and 16-h treated samples were also significantly greater than the $1-\mathrm{h}$, and the 8 -h significantly greater than the 4 -h samples $(P<0 \cdot 05$, Student-Newman-Keuls test).

expression of ICAM-1, observed in Fig. 5, for IL-1 $\beta$ concentrations above $1 \mathrm{ng} / \mathrm{ml}$ was not statistically significant $(P>0.05$ for the 3 and $10 \mathrm{ng} / \mathrm{ml}$ treated samples vs the $1 \mathrm{ng} / \mathrm{ml}$ sample).

\section{Response of the stimulation of expression of ICAM-1 mRNA to inhibition of protein synthesis}

In order to determine whether protein synthesis was required for up-regulation of ICAM-1 mRNA by TNF- $\alpha$, WISH cells were pretreated with CHX $30 \mathrm{~min}$ before the addition of $50 \mathrm{ng} / \mathrm{ml} \mathrm{TNF}-\alpha$. As shown in Fig. 6, the stimulation of ICAM-1 mRNA expression in WISH cells by TNF- $\alpha$ was not inhibited by this treatment. Control treatments with CHX alone resulted in no enhancement of ICAM-1 expression.

\section{Production of ICAM-1 protein in WISH cells treated with TNF- $\alpha$ and IL-1 $\beta$}

To evaluate the extent to which the increase in ICAM-1 mRNA stimulated by the proinflammatory cytokines is reflected in an increase in ICAM-1 protein, cellular lysates were assayed for ICAM-1 by ELISA. A hypotonic lysis buffer containing a non-ionic detergent compatible with the assay was used to suspend the membrane and cytoplasmic components of the cell. As shown in Fig. 7, ICAM-1 protein becomes significantly greater by $4 \mathrm{~h}$ of treatment in WISH cells exposed to either $1.0 \mathrm{ng} / \mathrm{ml} \mathrm{IL-1} \beta$ or $50 \mathrm{ng} / \mathrm{ml} \mathrm{TNF- \alpha}$ than in cells receiving vehicle alone. Although the response to the two cytokines is the same through $8 \mathrm{~h}$ of treatment, by $16 \mathrm{~h}$ the response to the latter exceeds that to the former by nearly twofold. At 


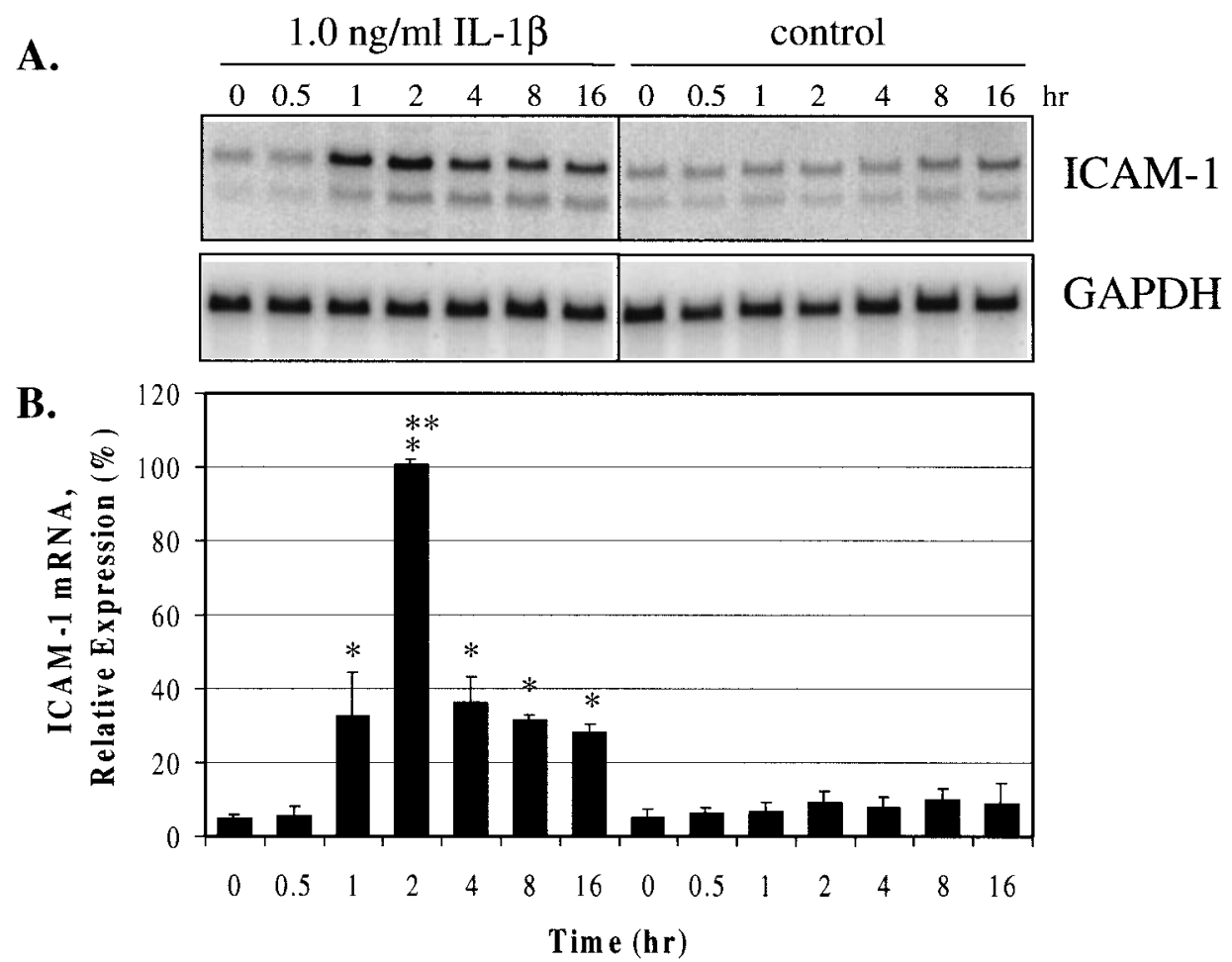

FIGURE 4. Time course of the stimulation of ICAM-1 mRNA expression in WISH cells following treatment with IL-1 $\beta$. WISH cells were treated with either $1.0 \mathrm{ng} / \mathrm{ml}$ IL-1 $\beta$ or vehicle and total RNA was extracted after $0,0 \cdot 5,1,2,4,8$, or $16 \mathrm{~h}$. (A) Representative northern blot probed for ICAM-1 and GAPDH: the treatments and times were as indicated above the blot. (B) Quantitative representation of ICAM-1 mRNA expression over the above time course. The data have been normalised to GAPDH and expressed relative to the same common reference sample as in Fig. 3 . They are plotted as means \pm S.E.M. ( $n=3$ independent experiments); $* P<0 \cdot 05$, significantly greater than the zero hour and corresponding vehicle-treated controls (Student-Newman-Keuls test); ** $P<0 \cdot 05$, significantly greater than at all other time points (Student-Newman-Keuls test).

this time point ICAM-1 protein levels were $6 \pm 0 \cdot 8$ - and $11 \pm 1$-fold (mean \pm s.E.M.) respectively for the two cytokines, over the corresponding vehicle-treated controls. No statistically significant change could be detected in the basal level of ICAM-1 over the entire 24-h time course. Shedding of sICAM-1 into the media in response to the above cytokines over this time was not detected (data not shown).

\section{Treatment of amnion primary cultures with TNF- $\alpha$}

TNF- $\alpha$ also stimulates expression of ICAM-1 in primary amnion cells in culture (Fig. 8). This increased expression became detectable at $2 \mathrm{~h}$, with the 8 -h time point exhibiting the highest expression.
Primary cultures of amnion cells did not exhibit detectable basal expression of ICAM-1. As with the WISH cells, TNF- $\alpha$ induced expression of ICAM-1 by the amnion cells remained elevated through $16 \mathrm{~h}$.

A constitutively expressed mRNA migrating slightly slower than the $3.2 \mathrm{~kb}$ ICAM-1 message was faintly detectable on amnion cell RNA northern blots (Fig. 8). Use of the $1.5 \mathrm{~kb}$ probe did not eliminate the band. As observed with WISH cell RNA, the $1.5 \mathrm{~kb}$ probe did eliminate detection of a very small $(0 \cdot 2 \mathrm{~kb})$ RNA (not shown).

\section{DISCUSSION}

Expression of ICAM-1 mRNA and the regulation thereof have been evaluated for the first time in 

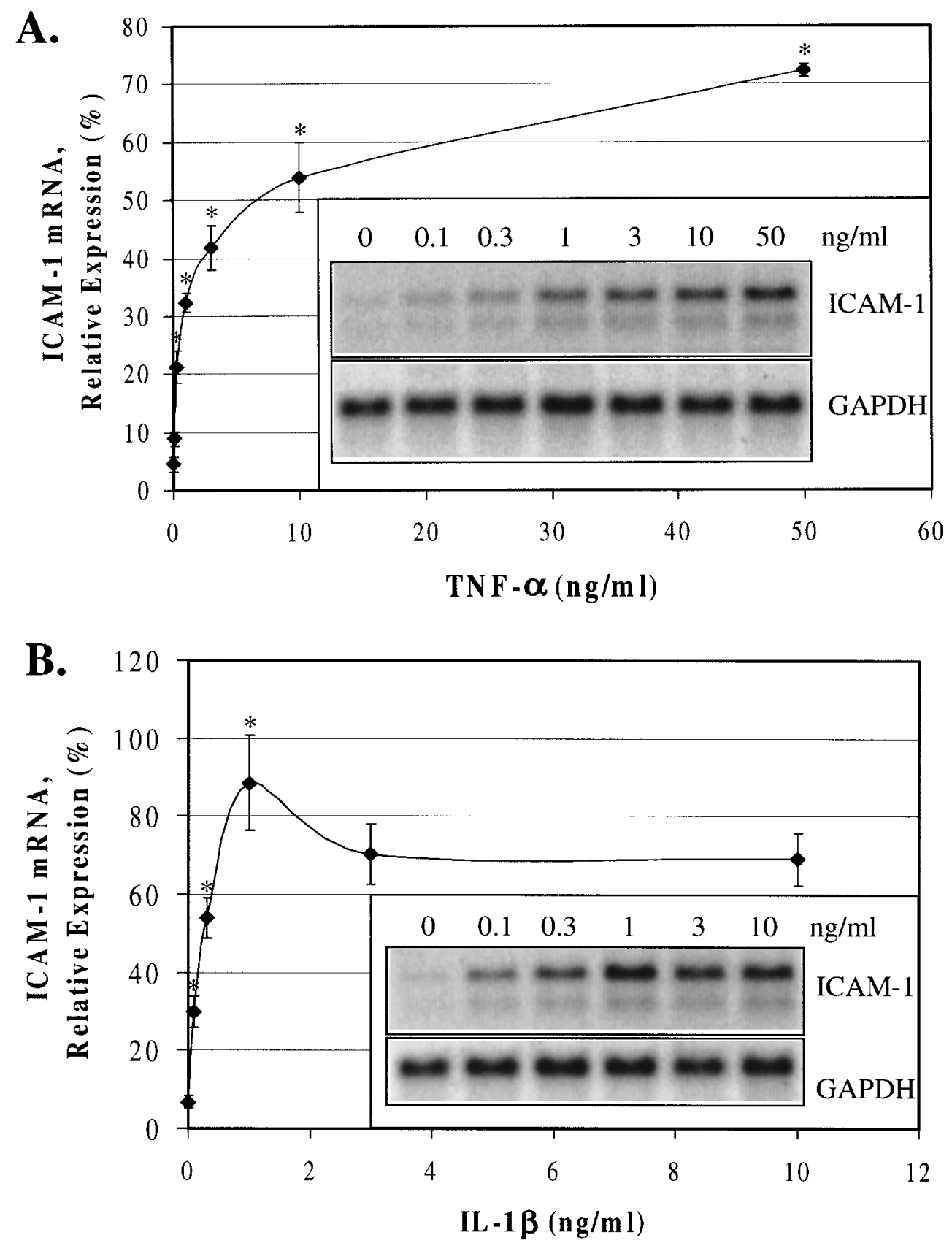

FIGURE 5. Concentration dependence of the stimulation of ICAM-1 expression in WISH cells by TNF- $\alpha$ or IL- $1 \beta$. WISH cells were treated for $2 \mathrm{~h}$ with (A) vehicle or $0 \cdot 1,0 \cdot 3,1,3$,

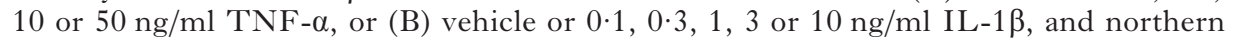
analyses for ICAM-1 mRNA were performed on total RNA extracted from the cells. The data have been normalised to GAPDH and expressed relative to the common reference sample (means \pm S.E.M., $n=3$ experiments). Representative blots are shown as insets. * $P<0 \cdot 05$, significantly greater than expression in cells treated with vehicle or all lower concentrations of cytokine (Student-Newman-Keuls test). 


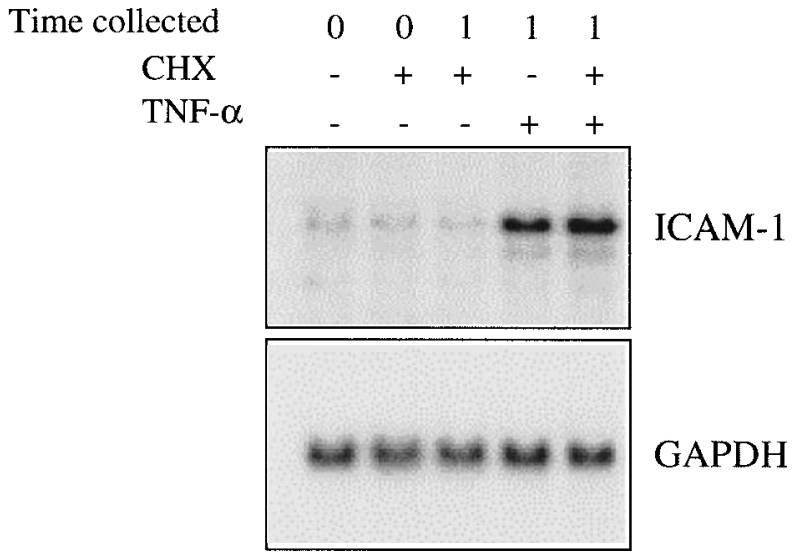

FIGURE 6. Northern blot analysis of RNA extracted from confluent cultures of the WISH cells which were

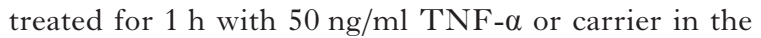
presence or absence of $10 \mu \mathrm{g} / \mathrm{ml} \mathrm{CHX} 30 \mathrm{~min}$ prior to addition of TNF- $\alpha$. The times of collection noted above the blot are relative to the time of addition of TNF- $\alpha$. The blot was probed in Quikhyb solution with $2.9 \mathrm{~kb}$ ICAM-1 and the GAPDH probes. Exposed at $500 \mu \mathrm{m}$ resolution. (Representative of 2 independent experiments.)

amnion cell cultures. We have also recently demonstrated the expression of this mRNA in amnion tissues taken during the latter half of gestation (Marvin et al. 1998). The cDNA probes utilised in this study were prepared by RT-PCR from RNA from appropriately treated HL60 cells. These cells are known to express ICAM-1 following induction to differentiate (Staunton et al. 1988). Restriction analysis indicated that the desired PCR products had been obtained. Furthermore, the major and minor transcripts detected on northern blots $(3 \cdot 2$ and $2 \cdot 3 \mathrm{~kb}$ respectively) correspond within experimental error to those reported previously ( 3.3 and $2 \cdot 4 \mathrm{~kb}$ respectively) (Staunton et al. 1988).

Regulation by pro-inflammatory cytokines of ICAM-1 mRNA in both amnion cell culture models was consistent with previous studies on endothelial cells (Pober et al. 1986, 1987, Dustin \& Springer 1988, Springer 1994) and on other epithelial culture systems (Sippy et al. 1995, Ciprandi et al. 1996, Khair et al. 1996, Iwata et al. 1997). Specifically, TNF- $\alpha$ and IL- $1 \beta$, used at concentrations previously demonstrated in this laboratory and by others to stimulate prostaglandin production and expression of PGHS-2 mRNA (Albert et al. 1994, Perkins \& Kniss 1997, Gilmour et al. 1998, Hansen et al. 1998), dramatically increased levels of ICAM-1 mRNA in the WISH cell model. As with PGHS-2 this enhanced expression was

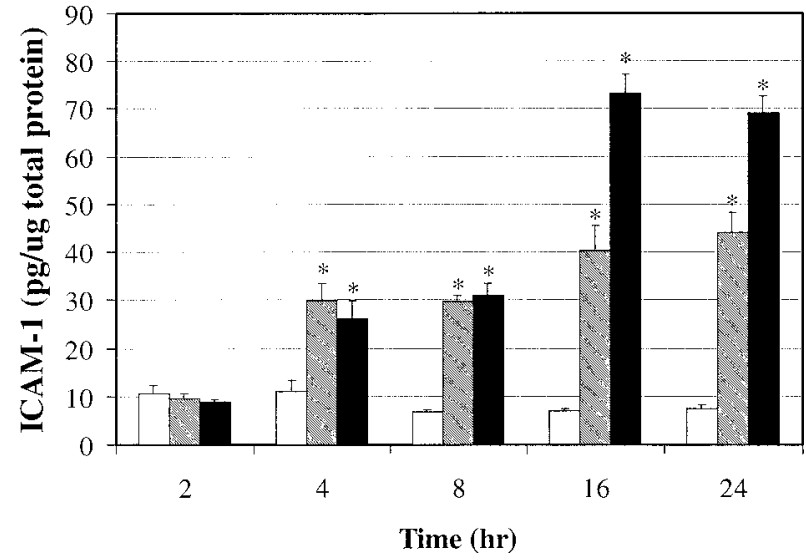

FIGURE 7. ELISA analysis of the time course of the production of ICAM-1 protein in WISH cells following treatment with IL-1 $\beta$ or TNF- $\alpha$. Cellular proteins collected from WISH cells after incubation with vehicle (open bars), $1 \cdot 0 \mathrm{ng} / \mathrm{ml} \mathrm{IL-1 \beta}$ (diagnonal striped bars), or $50 \mathrm{ng} / \mathrm{ml} \mathrm{TNF}-\alpha$ (solid bars) for the times indicated were assayed for ICAM-1 by ELISA and normalised for total protein estimated by the BCA method. Results of three independent experiments with three replicate samples per condition were combined and expressed as means \pm s.E.M.; $* P<0 \cdot 05$, significantly greater than the zero hour and corresponding vehicle-treated controls (Student-Newman-Keuls test). TNF- $\alpha$ also stimulated significantly more at the 16 - and 24 -h time points than IL-1 $\beta$.

independent of protein synthesis. TNF- $\alpha$ similarly stimulated ICAM-1 expression in primary amnion cell cultures, albeit with several hours delay. Although the cause of this delay, which has also been observed with PGHS-2 (W R Hansen \& M D

\section{0ng/ml TNF $\alpha$}

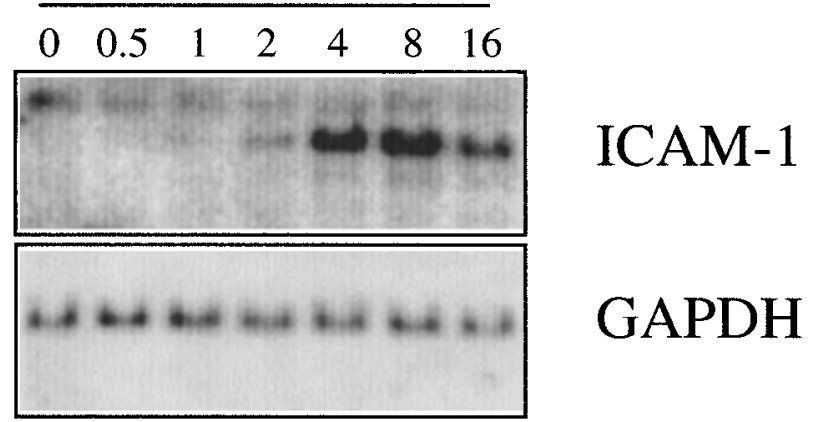

FIGURE 8. Northern blot analysis of RNA extracted from primary cultures of human amnion cells treated at confluence (day 5 of culture) with TNF- $\alpha$ for the times (h) indicated above. Probed in QuikHyb solution and exposed at $500 \mu \mathrm{m}$ resolution. (Representative of 3 independent experiments.) 
Mitchell, unpublished data), has yet to be determined, it is clear that the capacity to express ICAM-1 in response to TNF- $\alpha$ is not peculiar to the transformed cell line.

These results are pertinent to the study of preterm labour. First, the concentration in amniotic fluid of one of the ICAM-1 gene products, sICAM-1, has been reported to correlate to the degree of prematurity in cases of IUGR-associated preterm labour (Salafia et al. 1993). Secondly, a massive secretion of pro-inflammatory cytokines, including those used in the present study, has been shown to accompany intrauterine infectionassociated preterm labour (Romero et al. 1989a,b). Finally, a number of reports have suggested that elevated levels of these cytokines also accompany cases of preterm labour in which there is no apparent association with clinical or pathological signs of infection (Romero et al. 1990, Dudley et al. $1996 a, b)$. The present study shows that amnionderived cells are capable of expressing ICAM-1 and suggests that inflammatory cytokines reaching the amnion would likely result in enhanced expression of this gene. Consequently, a broader range of aetiologies of preterm labour than previously reported (Salafia et al. 1993) would be expected to result in its expression.

The classic role of ICAM-1 is in recruitment of leukocytes to sites of inflammation (Carlos \& Harlan 1994, Springer 1994). The engagement of ICAM-1 on the surface of activated endothelium by $\alpha_{L^{-}}$ or $\alpha_{\mathrm{M}}-/ \beta_{2}$-integrin expressing leukocytes promotes their transendothelial migration (Smith et al. 1988, 1989, Furie et al. 1991, 1992, Meerschaert \& Furie 1995). Chemoattractants increase this interaction by regulating the expression or adhesiveness of these integrins on the circulating cells (Smith et al. 1989, Tonnesen et al. 1989, Huber et al. 1991, Brady et al . 1995). Interestingly, the ICAM-1-dependent adhesion and penetration phases are distinct. The latter phase can be blocked by interfering with cytoplasmic $\mathrm{Ca}^{2+}$ transients which occur in the endothelial cells (Huang et al. 1993). In addition, the small inflammatory mediators, leukotriene (LT) $\mathrm{C}_{4}$ and histamine, initiate similar transients. Either the binding of the small mediators or of leukocytes increases the permeability of endothelial cell monolayers to both ions and albumin (Huang et al. 1993).

In allergic or infectious inflammation of lung, nasal or conjunctival tissues, epithelial as well as endothelial expression of ICAM-1 is observed (Khair et al. 1996, Canonica et al. 1997). This situation may be more analogous to that in fetal membranes that are expressing this adhesion molecule. Inhibition of the accumulation of leuko- cytes in these tissues or in the fluids on their apical surface occurs not only with topical histamine H1 receptor antagonists, which inhibit ICAM-1 expression (Ciprandi et al. 1996) or with antagonists to the receptors for the chemoattractant, $\mathrm{LTB}_{4}$ (Allen et al. 1996), but also with anti-ICAM-1 antibodies applied to the epithelium (Wegner et al. 1990). This suggests that engagement of ICAM-1 on these epithelia by leukocytes plays a significant role in the inflammatory response.

The fetal membranes and cells derived from them also possess considerable biosynthetic capacity for leukocyte chemoattractants. Under conditions of intrauterine infection the concentration of the chemokine, IL-8, in amniotic fluid rises dramatically (Saito et al. 1993). WISH and amnion cells have been demonstrated in culture to secrete IL-8 in response to pro-inflammatory cytokines (Trautman et al. 1992, Keelan et al. 1997a,b). In addition, fetal membrane tissue explants have been demonstrated to secrete $\mathrm{LTB}_{4}$ (Ticconi et al. 1995).

The availability of leukocytes to bind ICAM-1 expressing amnion epithelium would appear to be limited, because of its remoteness from the circulation. However, the stroma of the amnion contains resident fetal macrophages (Bulmer \& Johnson 1984). The neighbouring chorion also contains resident macrophages and, in addition, granulocytes and T-lymphocytes. Furthermore, infiltration of the chorion by neutrophils is diagnostic of chorioamnionitis (Maudsley et al. 1966, Zaaijman et al. 1982, Lopez Bernal et al. 1989). Recruitment by the amnion of resident or infiltrating leukocytes from the chorion or decidua would require passage across the intervening chorionic cytotrophoblast layer. ICAM-1dependent migration of leukocytes across this layer is conceivable, since intravascular cytotrophoblasts have been reported to express ICAM-1 (Labarrere \& Faulk 1995). In addition, infiltrating neutrophils extensively damage the chorionic cytotrophoblast layer (Van Meir et al. 1996). A final potential pool of leukocytes which might interact with the amnion would be those in amniotic fluid (Romero et al. 1991). The latter, however, correlate to intraamniotic infection. They, therefore, would most likely have been recruited from the fetal lung and possibly the fetal membranes as part of the inflammatory response.

A direct role for ICAM-1 expression by the amnion in preterm labour is not immediately obvious. However, altered permeability of the amnion to cytokines and chemokines in the amniotic fluid or augmented infiltration of leukocytes through the amnion could influence inflammatory reactions and structural integrity of the fetal 
membranes. Furthermore, increased permeability of the membranes to protein might contribute to the presence of $\mathrm{fFN}$ and other diagnostic indicators in the cervico-vaginal fluid of women who are likely to go into preterm labour. From the present results it is clear that ICAM-1 expression by the amnion would be expected during infection-associated preterm labour. To the extent that this is reflected in sICAM-1 production under in vivo conditions, this gene product itself may serve as a valuable indicator of preterm labour. Evaluation of this potential will require further investigation.

\section{ACKNOWLEDGEMENTS}

We gratefully acknowledge Dr Les Myatt, University of Cincinnati, and Dr Kathryn Crosier, University of Auckland, for providing the cell lines used in this study and Dr Jeffrey Keelan, University of Auckland, for reviewing this manuscript. This work was supported by grants from the Health Research Council of New Zealand (grant number 97/017), the Royal Society of New Zealand Marsden Fund (grant number UOA-605), and the New Zealand Lottery Grants Board (grant number AP 57964).

\section{REFERENCES}

Albert TJ, Su H-C, Zimmerman PD, Iams JD \& Kniss DA 1994 Interleukin-1 $\beta$ regulates the inducible cyclooxygenase in amnion-derived WISH cells. Prostaglandins 48 401-416.

Allen DL, Hoffman WP, Marder P, Matchett MR, Leiter PA, Abbott DL \& Wolff RK 1996 The effects of LY293111Na, a leukotriene $\mathrm{B}_{4}$ receptor antagonist, on pulmonary neutrophilia and CD11b expression caused by inhalation of a leukotriene $\mathrm{B}_{4}$ aerosol in rhesus monkeys. Fournal of Pharmacology and Experimental Therapeutics 277 341-349.

Brady HR, Lamas S, Papayianni A, Takata S, Matsubara M \& Marsden PA 1995 Lipoxygenase product formation and cell adhesion during neutrophil-glomerular endothelial cell interaction. American Yournal of Physiology 268 F1-F12.

Brown T \& Mackey K 1997 Analysis of RNA by northern and Slot blot hybridization. In Current Protocols in Molecular Biology, pp 4.9.1-4.9.16. Eds FM Ausubel, R Brent, RE Kingston, DD Moore, JG Seidman, JA Smith, K Struhl, LM Albright, DM Coen, A Varki \& VB Chanda. New York, USA: John Wiley \& Sons, Inc.

Bulmer JN \& Johnson PM 1984 Macrophage populations in the human placenta and amniochorion. Clinical and Experimental Immunology 57 393-403.

Carlos TM \& Harlan JM 1994 Leukocyte-endothelial adhesion molecules. Blood 84 2068-2101.

Canonica GW, Ciprandi G, Passalacqua G, Pesce G, Scordamaglia A \& Bagnasco M 1997 Molecular events in allergic inflammation: experimental models and possible modulation. Allergy 52 (Suppl 34) 25-30.

Chomczynski P 1992 Solubilization in formamide protects RNA from degradation. Nucleic Acids Research 20 3791-3792.
Chomczynski P \& Sacchi N 1987 Single step method of RNA isolation by acid guanidinium thiocyanate-phenol-chloroform extraction. Analytical Biochemistry 162 156-159.

Ciprandi G, Pronzato C, Passalacqua G, Ricca V, Grogen J, Mela GS, Varese P, Bertolini C, Bagnasco M \& Canonica GW 1996 Topical azelastine reduces eosinophil activation and intercellular adhesion molecule-1 expression on nasal epithelial cells: an antiallergic activity. Fournal of Allergy and Clinical Immunology 98 1088-1096.

Committee to Study the Prevention of Low Birthweight, Division of Health Promotion and Disease Prevention, Institute of Medicine 1985 Preventing Low Birthweight. Washington: National Academy Press.

Copper RL, Goldenberg RL, Creasy RK, DuBard MB, Davis RO, Entman SS, Iams JD \& Cliver SP 1993 A multicenter study of preterm birth weight and gestational age-specific neonatal mortality. American Fournal of Obstetrics and Gynecology 168 78-83.

Creasy RK 1993 Preterm birth prevention: where are we? American Fournal of Gynecology 168 1223-1230.

Damsky C, Sutherland A \& Fisher S 1993 Extracellular matrix 5: adhesive interactions in early mammalian embryogenesis, implantation, and placentation. FASEB Fournal 7 1320-1329.

Damsky CH, Librach C, Lim K, Fitzgerald ML, McMaster MT, Janatpour M, Zhou Y, Logan SK \& Fisher SJ 1994 Integrin switching regulates normal trophoblast invasion. Development 120 3657-3666.

Dudley DJ, Collmer D, Mitchell MD \& Trautman MD $1996 a$ Inflammatory cytokine mRNA in human gestational tissues: implications for term and preterm labor. Fournal of the Society for Gynecologic Investigation 3 328-335.

Dudley DJ, Hunter C, Varner MW \& Mitchell MD $1996 b$ Elevation of amniotic fluid interleukin- 4 concentrations in women with preterm labor and chorioamnionitis. American Fournal of Perinatology 13 443-447.

Dustin ML \& Springer TA 1988 Lymphocyte functionassociated antigen-1 (LFA-1) interaction with intercellular adhesion molecule-1 (ICAM-1) is one of at least three mechanisms for lymphocyte adhesion to cultured endothelial cells. Fournal of Cell Biology 107 321-331.

Furie MB, Tancinco MC \& Smith CW 1991 Monoclonal antibodies to leukocyte integrins CD11a/CD18 and CD11b/CD18 or intercellular adhesion molecule-1 inhibit chemoattractant-stimulated neutrophil transendothelial migration in vitro. Blood 78 2089-2097.

Furie MB, Burns MJ, Tancinco MC, Benjamin CD \& Lobb RR 1992 E-selectin (endothelial-leukocyte adhesion molecule-1) is not required for the migration of neutrophils across IL-1-stimulated endothelium in vitro. Fournal of Immunology 148 2395-2404.

Gardner MO \& Goldenberg RL 1995 The clinical use of antenatal steroids. Clinical Obstetrics and Gynecology 38 746-754.

Gilmour JS, Hansen WR, Miller HC, Keelan JA, Sato TA \& Mitchell MD 1998 Effects of interleukin-4 on the expression and activity of prostaglandin endoperoxide $\mathrm{H}$ synthase- 2 in amnion-derived WISH cells. Fournal of Molecular Endocrinology 21 317-325.

Hansen WR, Sato T \& Mitchell MD 1998 Tumor necrosis factor-alpha stimulates increased expression of prostaglandin endoperoxide-H synthase type-2 mRNA in amnion-derived WISH cells. Fournal of Molecular Endocrinology 20 221-230.

Hayflick L 1961 The establishment of a line (WISH) of human amnion cells in continuous cultivation. Experimental Cell Research 23 14-20.

Higby K, Xenakis EM-J \& Pauerstein CJ 1993 Do tocolytic agents stop preterm labor? A critical and comprehensive 
review of efficacy and safety. American Fournal of Obstetrics and Gynecology 168 1247-1259.

Hiscott J, Marois J, Garoufalis J, D'Addario M, Roulston A, Kwan I, Pepin N, Lacoste J, Nguyen H, Bensi G \& Fenton M 1993 Characterization of a functional NF-kappaB site in the human interleukin-1 beta promoter: evidence for a positive autoregulatory loop. Molecular and Cellular Biology 13 6231-6240.

Huang AJ, Manning JE, Bandak TM, Ratau MC, Hanser KR \& Silverstein SC 1993 Endothelial cell cytosolic free calcium regulates neutrophil migration across monolayers of endothelial cells. Fournal of Cell Biology 120 1371-1380.

Huber AR, Kunkel SL, Todd III RF \& Weiss 1991 Regulation of transendothelial neutrophil migration by endogenous interleukin-8. Science 254 99-102.

Iams JD, Johnson FF \& Parker M 1994 A prospective evaluation of the signs and symptoms of preterm labor. Obstetrics and Gynecology 84 227-230.

Inglis SR, Jeremias J, Kuno K, Lescale K, Peeper Q, Chervenak FA \& Witkin SS 1994 Detection of tumor necrosis factor- $\alpha$, interleukin-6, and fetal fibronectin in the lower genital tract during pregnancy: relation to outcome. American Fournal of Obstetrics and Gynecology 171 5-10.

Iwata M, Sawada S, Saw M \& Thoft RA 1997 Mechanisms of lymphocyte adhesion to cultured human corneal epithelial cells. Current Eye Research 16 751-760.

Keelan JA, Sato TS \& Mitchell MD $1997 a$ Interleukin (IL)-6 and IL- 8 production by human amnion: regulation by cytokines, growth factors, glucocorticoids, phorbol ester, and bacterial lipopolysaccharide. Biology of Reproduction $\mathbf{5 7}$ 1438-1444.

Keelan JA, Sato TS \& Mitchell MD $1997 b$ Regulation of interleukin (IL)- 6 and IL- 8 production in an amnion-derived cell line by cytokines, growth factors, glucocorticoids, and phorbol esters. American Fournal of Reproductive Immunology 38 272-278.

Khair OA, Davies RJ \& Devalia JL 1996 Bacterial-induced release of inflammatory mediators by bronchial epithelial cells. European Respiratory Fournal 9 1913-1922.

Kwee L, Baldwin HS, Shen HM, Stewart CL, Buck C, Buck CA \& Labow MA 1995 Defective development of the embryonic and extra-embryonic circulatory systems in vascular cell adhesion molecule (vcam-1) deficient mice. Development 121 489-503.

Labarrere CA \& Faulk WP 1995 Intercellular adhesion molecule-1 (ICAM-1) and HLA-DR antigens are expressed on endovascular cytotrophoblasts in abnormal pregnancies. American Fournal of Reproductive Immunology 33 47-53.

Ledebur HC \& Parks TP 1995 Transcriptional regulation of the intercellular adhesion molecule- 1 gene by inflammatory cytokines in human endothelial cells: essential roles of a variant NF- $\mathrm{KB}$ site and $\mathrm{p} 65$ homodimers. Fournal of Biological Chemistry 270 933-943.

Lockwood CJ 1995 The diagnosis of preterm labor and the prediction of preterm delivery. Clinical Obstetrics and Gynecology 38 675-687.

Lockwood CJ, Wein R, Lapinski R, Casal D, Berkowitz G, Alvarez M \& Berkowitz RL 1993 The presence of cervical and vaginal fetal fibronectin predicts preterm delivery in an inner-city obstetric population. American Fournal of Obstetrics and Gynecology 169 798-804.

Lopez Bernal A, Hansell DJ, Khong TY, Keeling JW \& Turnbull AC 1989 Prostaglandin E production by the fetal membranes in unexplained preterm labour and preterm labour associated with chorioamnionitis. British fournal of Obstetrics and Gynaecology 96 1133-1139.

Lyall F, Greer IA, Boswell F, Young A, Macara M \& Jeffers MD 1995 Expression of cell adhesion molecules in placentae from pregnancies complicated by pre-eclampsia and intrauterine growth retardation. Placenta 16 579-587.

McCormick MC 1985 The contribution of low birth weight to infant mortality and childhood morbidity. New England Fournal of Medicine 312 82-90.

Marvin KW, George MD, Fujimoto W, Saunders NA, Bernacki SH \& Jetten AM 1992 Cornifin: a new cross-linked envelope precursor in keratinocytes, down-regulation by retinoids. Proceedings of the National Academy of Sciences of the USA 89 11026-11030.

Marvin KW, Hansen WR, Gilmour JS, Keelan JA, Miller HC \& Mitchell MD 1998 Enhanced expression of intercellular adhesion molecule-1 (ICAM-1) in amnion obtained after labor at term and preterm. Fournal of the Society for Gynecologic Investigation 5 (Suppl) 191A.

Maudsley RF, Brix GA, Hinton NA, Robertson EM, Bryans AM \& Haust MD 1966 Placental inflammation and infection. American Fournal of Obstetrics and Gynecology 95 648-659.

Meerschaert J \& Furie MB 1995 The adhesion molecules used by monocytes for migration across endothelium include CD11a/CD18, CD11b/CD18, and VLA-4 on monocytes and ICAM-1, VCAM-1, and other ligands on endothelium. Fournal of Immunology 154 4099-4112.

Mercer BM, Goldenberg RL, Das A, Moawad AH, Iams JD, Meis PJ, Copper RL, Johnson F, Thom E, McNellis D, Miodovnik M, Menard MK, Caritis SN, Thurnau GR, Bottoms SF \& Roberts J 1996 The preterm prediction study: a clinical risk assessment system. American fournal of Obstetrics and Gynecology 174 1885-1893.

Morrison JC 1990 Preterm birth: a puzzle worth solving. Obstetrics and Gynecology $765 \mathrm{~s}-12 \mathrm{~s}$.

Perkins DJ \& Kniss DA 1997 Tumor necrosis factor- $\alpha$ promotes sustained cyclooxygenase-2 expression: attenuation by dexamethasone and NSAIDs. Prostaglandins 54 727-743.

Pober JS, Gimbrone MA Jr, Lapierre LA, Mendrick DL, Fiers W, Rothlein R \& Springer TA 1986 Overlapping patterns of activation of human endothelial cells by interleukin 1, tumor necrosis factor, and immune interferon. fournal of Immunology 137 1893-1896.

Pober JS, Lapierre LA, Stolpen AH, Brock TA, Springer TA, Fiers W, Bevilacqua MP, Mendrick DL \& Gimbrone MA Jr 1987 Activation of cultured human endothelial cells by recombinant lymphotoxin: comparison with tumor necrosis factor and interleukin 1 species. Fournal of Immunology 138 3319-3324.

Redinbaugh MG \& Turley RB 1986 Adaptation of the bicinchoninic acid protein assay for use with microtiter plates and sucrose gradient fractions. Analytical Biochemistry 153 $267-271$.

Roebuck KA, Rahman A, Lakshminarayanan V, Janakidevi K \& Malik $\mathrm{AB} 1995 \mathrm{H}_{2} \mathrm{O}_{2}$ and tumor necrosis factor- $\alpha$ activate intercellular adhesion molecule-1 (ICAM-1) gene transcription through distinct cis-regulatory elements within the ICAM-1 promoter. Fournal of Biology and Chemistry 270 18966-18974.

Romero R, Monogue KR, Mitchell MD, Wu YK, Oyarzun E, Hobbins JC \& Cerami A $1989 a$ Infection and labor IV. Cachetin-tumor necrosis factor in the amniotic fluid of women with intraamniotic infection and preterm labor. American Fournal of Obstetrics and Gynecology 161 336-341.

Romero R, Brody DT, Oyarzun E, Mazor M, Wu YK, Hobbins JC \& Durum SK 1989 b Infection and labor III. Interleukin-1: a signal for the onset of parturition. American Fournal of Obstetrics and Gynecology 160 1117-1123.

Romero R, Avila C, Santhanam U \& Sehgal PB 1990 Amniotic fluid interleukin-6 in preterm labor. Fournal of Clinical Investigation 85 1392-1400. 
Romero R, Quintero R, Nores J, Avila C, Mazor M, Hanaoka S, Hagay Z, Merchant L \& Hobbins JC 1991 Amniotic fluid white blood cell count: a rapid and simple test to diagnose microbial invasion of the amniotic cavity and predict preterm delivery. American Fournal of Obstetrics and Gynecology 165 821-830.

Saito S, Kasahara T, Kato Y, Ishihara Y \& Ichijo M 1993 Elevation of amniotic fluid interleukin 6 (IL-6), IL-8 and granulocyte colony stimulating factor (G-CSF) in term and preterm parturition. Cytokine $\mathbf{5} 81-88$.

Salafia CM, Devore GR, Mainolfi E, Kelly J, Pezzullo JC \& Rothlein R 1993 Circulating intercellular adhesion molecule- 1 in amniotic fluid, maternal serum $\alpha$-fetoprotein levels, and intrauterine growth retardation. American fournal of Obstetrics and Gynecology 169 830-834.

Sambrook J, Fritsch EF \& Maniatis T 1989 Molecular Cloning: A Laboratory Manual, edn 2. New York: Cold Spring Harbor Laboratory Press.

Scott DT \& Spiker D 1989 Research on the sequelae of prematurity: early learning, early interventions, and later outcomes. Seminars in Perinatology 13 495-505.

Sippy BD, Hofman FM, He S, Osusky R, Sheu SJ, Walker SM, Ryan SJ \& Hinton DR 1995 SV40-immortalized and primary cultured human retinal pigment epithelial cells share similar patterns of cytokine-receptor expression and cytokine responsiveness. Current Eye Research 14 495-503.

Smith CW, Rothlein R, Hughes BJ, Mariscalco MM, Rudloff HE, Schmalstieg FC \& Anderson DC 1988 Recognition of an endothelial determinant for CD 18-dependent human neutrophil adherence and transendothelial migration. Fournal of Clinical Investigation 82 1746-1756.

Smith CW, Marlin SD, Rothlein R, Toman C \& Anderson DC 1989 Cooperative interactions of LFA-1 and Mac-1 with intercellular adhesion molecule-1 facilitating adherence and transendothelial migration of human neutrophils in vitro. Fournal of Clinical Investigation 83 2008-2017.

Springer TA 1990 Adhesion receptors of the immune system. Nature 346 425-433.

Springer TA 1994 Traffic signals for lymphocyte recirculation and leukocyte emigration: the multistep paradigm. Cell $\mathbf{7 6}$ $301-314$

Staunton DE, Marlin SD, Stratowa C, Dustin ML \& Springer TA 1988 Primary structure of ICAM-1 demonstrates interaction between members of the immunoglobulin and integrin supergene families. Cell 52 925-933.

Tazawa R, Xu X, Wu KK \& Wang L 1994 Characterization of the genomic structure, chromosome location and promoter of human prostaglandin $\mathrm{H}$ synthase-2 gene. Biophysical and Biochemical Research Communications 203 109-199.
Ticconi C, Zicari A, Pontieri G, Salerno A, Mauri A, Piccione E \& Pasetto N 1995 Release of arachidonic acid metabolites by human fetal membranes: interrelationship between leukotriene B4 and prostaglandin E2. Prostaglandins 49 197-204.

Tomassini JE, Graham D, DeWitt CM, Lineberger DW, Rodkey JA \& Colonno RJ 1989 cDNA cloning reveals that the major group rinovirus receptor on HeLa cells is intercellular adhesion molecule-1. Proceedings of the National Academy of Sciences of the USA 86 4907-4911.

Tonnesen MG, Anderson DC, Springer TA, Knedler A, Avdi N \& Henson PM 1989 Adherence of neutrophils to cultured human microvascular endothelial cells: stimulation by chemotactic peptides and lipid mediators and dependence upon the Mac-1, LFA-1, p150,95 glycoprotein family. Fournal of Clinical Investigation 83 637-646.

Trautman MS, Dudley DJ, Edwin SS, Collmer D \& Mitchell MD 1992 Amnion cell biosynthesis of interleukin-8: regulation by inflammatory cytokines. Fournal of Cell Physiology 153 38-43.

Tso JY, Sun XH, Kao TH, Reece KS \& Wu R 1985 Isolation and characterization of rat and human glyceraldehyde-3phosphate dehydrogenase cDNAs: genomic complexity and molecular evolution of the gene. Nucleic Acids Research 13 2485-2502.

Van Meir CA, Sangha RK, Walton JC, Matthews SG, Keirse MJ \& Challis JR 1996 Immunoreactive 15hydroxyprostaglandin dehydrogenase $(\mathrm{PGDH})$ is reduced in fetal membranes from patients at preterm delivery in the presence of infection. Placenta 17 291-297.

Vollberg TM Sr, George MD \& Jetten 1991 Induction of extracellular matrix gene expression in normal human keratinocytes by transforming growth factor $\beta$ is altered by cellular differentiation. Experimental Cell Research 193 93-100.

Wegner CD, Gundel RH, Reilly P, Haynes N, Letts LG \& Rothlein R 1990 Intercellular adhesion molecule-1 (ICAM-1) in the pathogenesis of asthma. Science $\mathbf{2 4 7}$ 456-459.

Yang JT, Rayburn H \& Hynes RO 1995 Cell adhesion events mediated by $\alpha 4$ integrins are essential in placental and cardiac development. Development 121 549-560.

Zaaijman J du T, Wilkinson AR, Keeling JW, Mitchell RG \& Turnbull AC 1982 Spontaneous premature rupture of membranes: bacteriology, histology and neonatal outcome. Fournal of Obstetrics and Gynaecology 2 155-160.

REVISED MANUSCRIPT RECEIVED 15 October 1998 